fashion of former times, and it is becoming yearly more expensive and difficult for one in private life to keep abreast of the times even by specializing in a restricted field.

And opportunities for one to do good scientific work with any chance of earning expense money are exceeding rare-unless a salaried position is secured in adrance.

The increased number of scientific and educational institutions apparently fail to give equal facilities with the past to the independent youthful student. And the increase in volume of literature renders it impossible for any one not connected with some wealthy institution, or with large private means, to keep posted on proposed changes in nomenclature -to say nothing of the new discoveries being made.

There is no decrease in the interest of the general public in scientific work, but the existing state of affairs is probably due chiefly to expansion and greatly increased activity, resulting in a mass of unassimilated data and museums bursting beyond the bounds set by their founders.

\section{R. OrCutt}

\section{SCIENTIFIC BOOKS}

A Cyclopedia of American Medical Biography, Comprising the Lives of Eminent Deceased Physicians and Surgeons from 1610 to 1910. By Howard A. Kelly, M.D. Mlustrated with Portraits. Two Volumes. Philadelphia and London, W. B. Saunders Company. 1912.

This work, handsome in typography and execution, and containing over twelve hundred biographies of prominent deceased American physicians, written, for the most part, in clean-cut style by various competent hands, marks a distinct advance upon any of its predecessors in the same kind. Of the earlier dictionaries of American medical biography, those of Thacher (1828) and of the eminent surgeon S. D. Gross (1861) have a definite historic value, but the separate lives are usually too long, Thacher's, in particular, being surcharged with that florid, stilted spirit which, as Dr. Holmes wittily said, "has chewed the juice out of all the superlatives in the language in Fourth of July orations "; while the generous-minded Gross, incapable of saying anything unkind about his colleagues, was perhaps lacking in a right critical sense for that very reason. On the other hand, the later works-those of Atkinson (1878), Stone (1894) and Watson (1896) -abound in shorter biographies, but are, in the main, only directories of contemporary names. Dr. Kelly's Cyclopedia strikes a happy balance between the extremes of florid encomium and mediocre choice, consisting, in the main, of compact sketches of the lives of medical men who have "done things," and is thus a genuine contribution to medical history. Some of these worthies have described new diseases, have introduced new drugs, new operations or therapeutic procedures, or have otherwise contributed to the elevation of American medicine as chemists, botanists, zoologists, bibliophiles, military and naval surgeons or leaders in hygienic and social movements. The editor's plan in getting up this work was two-fold: one group of his coworkers took up the physicians who were of local importance as practitioners; the other group took care of those who are of scientific importance in relation to the specialties which they helped to advance. Some of the former class might seem at first sight of little consequence, yet it will appear that as teachers, organizers of schools and hospitals, pioneers in hygiene, whether in Canada, Mississippi or the far west, they have their place in the development of earlier American medicine, even though unknown in Berlin, St. Petersburg or Vienna. Professor Horatio C. Wood, the well-known therapeutist, relates that he was once asked by an eminent European authority for a list of the professors of his specialty in America. Upon receiving some forty or fifty names, the astounded savant replied: "In God's name who are these people? I never heard of more than one or two of them."1 Identical sensations are experienced in looking over the pages of Hirsch's "Biographisches Lexikon der Aerzte," that monument of

${ }^{1}$ Therap. Gaz., Detroit, 1911, XXXV., 92. 
German industry, especially when we come to the Meyers, Müllers, Schmidts and Schmitts. In other words, many able physicians are of that exclusively local importance so well described in Sainte Beuve's famous reply to Matthew Arnold: "He was important to us."

The introduction to this Cyclopedia consists of a series of valuable historical sketches on the development of different branches of medical science in America, notably those of Dr. Charles R. Bardeen on anatomy, Dr. Martin B. Tinker on surgery, and the histories of gynecology and obstetrics by Dr. Kelly himself. Few specialists seem to know or care so little about the history of their subject as gynecologists, probably because its development has been mainly technical and instrumental. In this regard, Dr. Kelly's sketch may be pronounced the best history of American gynecology that has yet appeared. It is memorable that operative gynecology, which had no existence as a specialty before the nineteenth century, is largely of American origin-in the first instance, an expedient to repair the sequels of backwoods obstetrics, and that its principal founders-McDowell, Marion Sims, Battey, Nott, Emmet, Bozeman, Gaillard Thomas-have been natives of the southern states.

Of especial historical interest are the notices of the colonial pamphleteers on smallpox and vaccination, the eighteenth century leaders (Rush, Morgan, Shippen, Physick), the pioneers in the surgery of the vascular system and the joints, the discoverers and exploiters of surgical anesthesia, the medical botanists, the medical jurisconsults, the important physicians of the Philadelphia group, and such later worthies as William Pepper, Walter Reed, Nicholas Senn or Elizabeth Blackwell. A biography of Hezekiah Beardsley, who, in 1788, described congenital hypertrophic stenosis of the pylorus, appears for the first time. There have been some omissions, perhaps unavoidable in works of this kind, in particular, Bowditch the physiologist, Bigelow the surgeon and the clinicians James Jackson and John K. Mitchell. Of John C. Otto, of Philadelphia, who, in 1803, first described hemophilia," perhaps "Non dat quod non habet." It is doubtful if Ricord and Brown Séquard can properly be included among Americans, since both were of French origin and all their life-work was identified with French medicine. On similar grounds, the omission of William Charles Wells, of South Carolina, memorable to physicists for his "Essay on Dew," seems not improper. A few points in priority in. Dr. Tinker's surgical introduction may be noted. It is frequently asserted that Dr. Dixi Crosby, of New Hampshire, was the first to perform the inter-scapular-thoracic amputation (excision of arm, scapula and clavicle) in 1836 . It had already been performed by Ralph Cuming, an English naval surgeon, in $1808 .^{3}$ Dupuytren cured a popliteal aneurism by compression in 1818," long before Jonathan Knight (1845) or O'Bryen Bellingham (1847), although Knight is undoubtedly entitled to the credit of doing this by digital compression. If Dr. Heine Marks really sutured a wounded heart before Farina and the Italian surgeons, it remains for him to prove it, as he mentions not a stitch of it in his published paper.

These volumes are embellished with many interesting portraits, those of Asa Gray, Fordyce Barker, Dewees, Agnew, Senn and Leidy being particularly good, while those of John Morgan, Physick, Horner (of Horner's muscle), Caspar Wistar, J. P. Mettauer and Willard Parker are probably copied for the first time. Many of the biographies have preserved traits of eccentricity in medical men who happened to be oddfish, more especially those from the piquant pen of Miss Davina Waterson. The following sentences of Joseph Leidy on introducing himself before a lecture are an example of the utter freedom from swagger and snobbery which distinguishes the true man of science:

My name is Joseph Leidy, doctor of medicine. I was born in this eity the ninth of September, 1823, and have lived here ever since. My father

'Med. Repository, New York, 1803, VI., 1-4.

${ }^{3}$ Lond. M. Gaz., 1829-30, V., 273.

' Bull. Fac. de méd. de Par., 1818, VI., 242.

${ }^{5}$ Med. Fortnightly, St. Louis, 1893, III., 44-46. 
was Philip Leidy, the hatter, on 3rd street above Vine; my mother, Katherine Mellick, but she died a few months after my birth, and my father married her sister Cristina, who was all in all to me, the one to whom I owe all that I am. At an early age $I$ took great delight in natural history, of which $I$ have reason to think $I$ know a little, and a little of that little I propose to teach you to-night.

One does not need to glance at the splendid head on the opposite page to realize that this great naturalist, whose "Rhizopods of North America," is one of our finest biological classics, was echt, in the exquisite Emersonian sense of living "from a great depth of being."

There are a few typographical errors here and there, but these things are of little consequence in a work which deserves to be in the library of every physician interested in the medical history of his country, and which will undoubtedly prove a valuable reference book in working scientific and public libraries.

F. H. Garrison

SURGeoN GENeral's Library

A Revision of the Cotylosauria of North America. By E. C. CAse. Washington, Carnegie Institution, Publication No. 145. 1911. Pp. 122, 14 plates.

It is now more than thirty-six years since the first Permian or Permo-Carboniferous reptiles were made known from North America by the late Professor Cope, who until his death twenty years or more later published at frequent intervals papers dealing with Paleozoic land vertebrates, coming chiefly from the famous deposits in northern Texas. As a pioneer, his work, here as elsewhere, was, of necessity, largely based upon fragmentary and imperfect material, material largely obscured by an obdurate matrix that only long and skilful preparation could remove. Few, if any, forms were known to him in anything approaching perfection or even completeness. As an inevitable result he left the subject in more or less confusion, notwithstanding the many important facts which he discovered. Many of his types were never figured nor even adequately described. In more recent years, beginning with Professor Case's collection in
Texas in 1897, the additions to our knowledge of these old land vertebrates made by him and others have been very considerable and of profound importance in paleontology. But much of the confusion and doubt regarding many of the original types, for the most part preserved in the American Museum of New York City, could only be removed by a careful revision of the whole group, based upon original specimens. This Professor Case has given us of the so-called order Cotylosauria in the present paper. At the present time there is, perhaps, no group of vertebrates of deeper interest to the student of evolution than the primitive reptiles and amphibians of the later Paleozoic, the forms from which all later vertebrates, save the fishes, have been derived. The many problems of the evolution of the Amphibia, and the origin and "radiation" of the Reptilia, are, until other fields have been discovered, dependent chiefly if not almost wholly on the Permo-Carboniferous deposits of Texas and the Rocky Mountains. No classification of the reptiles and amphibians will ever command any great degree of respect until these faunas have been well worked out; and, inasmuch as many of the problems of these groups are fundamental ones in many respects for all higher vertebrates, the interest attached to such studies as the present may be easily understood.

Professor Case did a very acceptable piece of work in his revision of the Pelycosauria, or the higher reptiles of the same fauna, published a few years ago. In the present work he has revised systematically and morphologically the numerous genera and species that have been proposed of the cotylosaurian reptiles, a group usually called an order though not distinguishable by very important characters from the Pelycosauria or Theromorpha. The chief value of the paper is the information given of the fragmentary and often unrecognizable types of Cope, as interpreted in the light of a more advanced knowledge of the group, by descriptions, comparisons and illustrations. Not much new material has been described nor have many new forms been added that had not been published by himself 